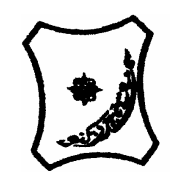

Bayero Journal of Pure and Applied Sciences, 1(1):58 - 61

Received: November, 2008

Accepted: November, 2008

\title{
TRACE ELEMENTS DETERMINATION IN MUNICIPAL WATER SUPPLY IN DAMATURU METROPOLIS, YOBE STATE, NIGERIA
}

\author{
* Emeka, D. O. ${ }^{1}$ and ${ }^{2}$ Weltime, O. M. \\ ${ }^{1}$ Department of Geography, Bukar Abba Ibrahim University, P.M.B. 1144, Damaturu, Yobe State. \\ ${ }^{2}$ Department of Chemistry, Bukar Abba Ibrahim University, P.M.B. 1144, Damaturu, Yobe State. \\ *Correspondence Author: emmyodan@Yahoo.uk Tel: 07039271480, 08025250182.
}

\begin{abstract}
Groundwater is the only source of drinking water for residents of Damaturu Metropolis. This is because surface water is very scarce as a result of the very low and erratic rainfall in the region. This study examines the presence of trace elements in the municipal water supplies of Damaturu Metropolis, Yobe state. The trace elements were determined using standard methods for the examination of water and wastewater from the US Environmental Protection Agency (USEPA). The result of the analysis shows that metals such as Lead, Cadmium, Zinc and Copper were not found in all the water samples, while other traces such as Fluoride and, Nitrite are within the permissible limits prescribed by W.H.O. Only the level of iron metal was found to exceed the limits set by WHO (1993). This study suggests that monitoring of the quality of groundwater should be undertaken regularly to identify the magnitude and source of toxic pollutants, which are responsible for the contamination of groundwater quality in the study area.
\end{abstract}

Key words: Contamination, Trace elements, Toxic, underground water.

\section{INTRODUCTION}

Groundwater contains major ions, trace metals and other toxic pollutants, in addition to bacteria (Zubair et $a l, 2008)$. The concentration of these substances in the aquifers is a function of the geological environment, composition of water, effect of storm water infiltration, water movement, its velocity, land use, rainfall and recharge mechanism. The increasing concentration of trace metals in ground water has generated a lot of concern in recent time. This has been attributed to human interference, proliferation of industries, and recent agricultural practice in urban areas where storm water flow recharges the aquifer. Effective retention of determinants depends upon soil types (Zubair and Farooq, 2008).

There are other potentially hazardous trace elements and compounds in urban soils. Sources of these include lumber treated with compounds to prevent rot and increase longevity, such as pentachloro-phenols, and by-products of combustion processes, such as poly-aromatic hydrocarbons. Even fertilizers can be a source of potentially hazardous trace elements. Prior to the more recent development of cleaner manufacturing processes, the inert materials used as blenders or fillers in phosphate fertilizers often-contained elevated levels of contaminants. Organic fertilizers may also have potentially hazardous trace elements. Poultry manure often contains arsenic that was in drugs administered to chickens for disease management. Similarly, pig manure usually has elevated levels of copper. Fertilizers or soil amendments containing sewage sludge or "bio-solids" were once potential sources of potentially hazardous trace elements, including lead, cadmium, and zinc (Zubair and Farooq, 2008). Due to government regulations contaminants in sewage sludge have been greatly reduced and pose virtually no threat when the product is used properly. Constituents such as trace metals are leached from the soil and move into aquifer systems and thus degrade the water quality. It therefore becomes necessary to assess, quantify and monitor the quality of ground water influenced by non-point source pollution as a result of storm water infiltration in the urban environment. This study is focused on the quality of ground water with reference to trace elements such as Fluoride, Lead, Cadmium, Zinc, Copper, Iron and Nitrite. This work is aimed at studying the presence of trace elements in groundwater in the study area and their potential health risk to the residents of Damaturu Metropolis.

\section{MATERIALS AND METHODS \\ Study Area}

Damaturu is located between latitude $11^{\circ} 44^{\prime} \mathrm{N}$ to $11^{\circ}$ $45^{\prime} \mathrm{N}$ and longitude $11^{\circ} 56^{\prime} \mathrm{E}$ to $11^{\circ} 58^{\prime} \mathrm{E}$. Damaturu is located in the semi-arid region of Nigeria with tropical continental climate. The climate is characterized by short wet season (June to August) and long dry season (October to May) with high temperature throughout the year. Annual rainfall is usually low, while evapotranspiration is high. Damaturu is a water deficit region with very low surface water during the rainy season. Damaturu is not drained by any river, hence absence of surface water resources. The town depends mainly on underground water resources which are usually accessed through drilling of borehole and artesian wells. 
Damaturu metropolis has no industrial establishment, but rather is dominated by agrarian economy. Studies of the effects of the agrarian economy (use of fertilizer, insecticides and pesticides) over the years on the underground water resources have not been carried out. Hence, it becomes imperative to assess the portability of the municipal water supply through the analysis of the trace element composition of the different water sources in Damaturu metropolis so as to appraise any health related problem that may be associated with the water supply.

Groundwater samples were collected from 9 boreholes and 1 cemented well on the $11^{\text {th }}$ of September 2008. Damaturu Metropolis is a Semi-Arid urban area with average annual rainfall of about $560 \mathrm{~mm}$. The low precipitation/rainfall accounts for a small fraction of the total recharge. There is also potential for recharge from sewers and drains which are designed to carry storm water out of the city. All these recharge sources eventually infiltrate and percolate down into the groundwater.

These samples covered Damaturu Metropolis and were collected at distances of $1 \mathrm{~km}$ to $1.5 \mathrm{~km}$ from each other in order to find the impact of pollutants on the hydrological system. All the boreholes and cemented well were regarded as potable and used for domestic purpose by the residents of Damaturu Metropolis.

White polyethylene bottles $\left(750 \mathrm{~cm}^{3}\right)$ were used for collecting samples. The bottles were rinsed first with distilled water before filling, rinsed a further two or three times with the water being sampled, and then the water sample was taken.

Standard methods for the examination of water and waste water from the US Environmental Protection Agency (USEPA) (1986) were used for the determination of trace elements/compounds such as fluoride, lead, cadmium, zinc, copper, iron and nitrite. All these elements and nitrite were analyzed using atomic absorption spectrophotometer. In the process of the analysis, two sets of internal standard were run, one at the beginning and the other in between the analyses to have a check on the accuracy and precision of the results following Balaram (1992) method. Lenntech W.H.O/E.U drinking water standards were used for comparison. The parameters were determined three times and the mean was taken.

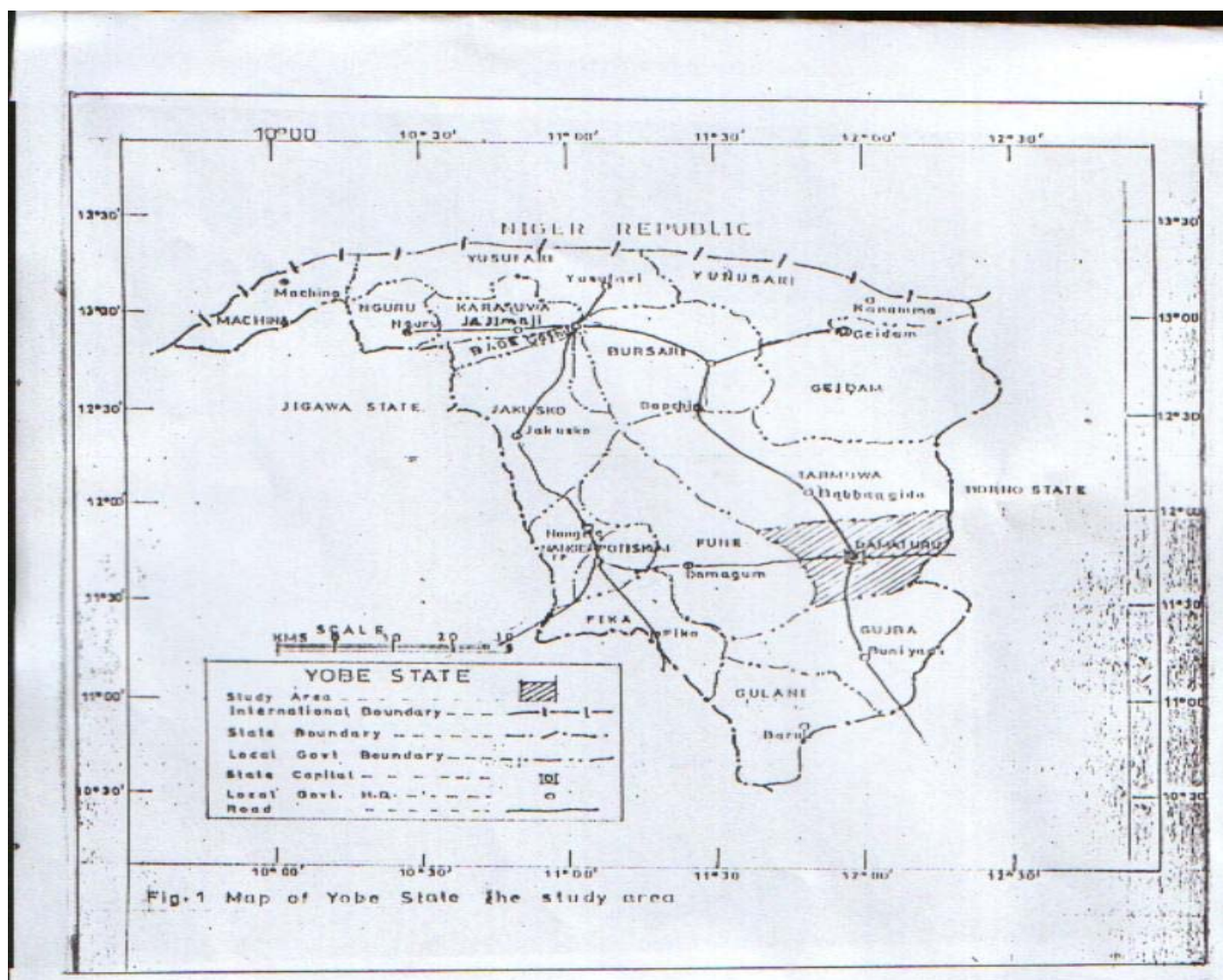

Figure 1: Map of Yobe State showing the study area. 
Bajopas Vol. 1 Number 1 December, 2008

RESULTS AND DISCUSSION

The result of the trace element determination in municipal water supply of Damaturu Metropolis is presented in Table1.

Table1: Trace element in sampled water in Damaturu Metropolis $\left(\mathrm{mg} / \mathrm{dm}^{3}\right)$

\begin{tabular}{lllllllll}
\hline $\begin{array}{l}\text { Sampled } \\
\text { water }\end{array}$ & $\mathbf{p H}$ & $\mathbf{F I}^{-}$ & $\mathbf{P b}$ & $\mathbf{C d}$ & $\mathbf{Z n}$ & $\mathbf{C o}$ & $\mathbf{F e}$ & $\mathbf{N O}_{\mathbf{2}^{-}}$ \\
\hline Powari & $6.71 \pm 0.01732$ & $1.048 \pm 0.02084$ & ND & ND & ND & ND & $0.4231 \pm 0.0002$ & $0.20 \pm 0.0015$ \\
(well) & & & & & & & & \\
Powari & $7.06 \pm 0.01528$ & $0.36 \pm 0.00577$ & ND & ND & ND & ND & $0.2014 \pm 0.0003$ & $0.041 \pm 0.0015$ \\
Nayinawa & $6.65 \pm 0.01528$ & $0.30 \pm 0.01247$ & ND & ND & ND & ND & $0.4432 \pm 0.0001$ & $0.15 \pm 0.0001$ \\
Hausari & $7.05 \pm 0.02646$ & $0.29 \pm 0.01527$ & ND & ND & ND & ND & $0.4002 \pm 0.0002$ & $0.036 \pm 0.0015$ \\
Nyanya & $6.85 \pm 0.00816$ & $0.32 \pm 0.00999$ & ND & ND & ND & ND & $0.3214 \pm 0.00015$ & $0.028 \pm 0.0057$ \\
Gwange & $7.12 \pm 0.01247$ & $0.42 \pm 0.01527$ & ND & ND & ND & ND & $0.2431 \pm 0.00015$ & $0.034 \pm 0.0015$ \\
Sabon & $7.18 \pm 0.01528$ & $0.36 \pm 0.01527$ & ND & ND & ND & ND & $0.1024 \pm 0.00026$ & $0.020 \pm 0.0015$ \\
pegi & & & & & & & & \\
New & $7.08 \pm 0.01528$ & $0.37 \pm 0.01527$ & ND & ND & ND & ND & $0.1822 \pm 0.00015$ & $0.019 \pm 0.0001$ \\
Jerusalem & & & & & & & & \\
Nassarawa & $7.14 \pm 0.01528$ & $0.32 \pm 0.01155$ & ND & ND & ND & ND & $0.2400 \pm 0.00015$ & $0.022 \pm 0.002$ \\
Tashan & $7.06 \pm 0.00999$ & $0.33 \pm 0.01527$ & ND & ND & ND & ND & $0.3034 \pm 0.00015$ & $0.026 \pm 0.002$ \\
Sassawa & & & & & & & & \\
\hline
\end{tabular}

Values are mean \pm standard error. ND = Not Determined

The result in the Table 1 above shows that the $\mathrm{pH}$ levels of the water samples investigated were within the W.H.O standards for $\mathrm{pH}(6.5-8.5)$ (WHO, 1993). Table 1 also shows that no traces of Lead, Cadmium, Zinc and Copper were found in all the water samples analyzed. Traces of Fluoride were found in all the water samples with the highest concentration of $0.48 \mathrm{mg} / \mathrm{dm}^{3}$ in Powari cemented well and the least $0.29 \mathrm{mg} / \mathrm{dm}^{3}$ in Hausari borehole water with an average of $0.355 \mathrm{mg} / \mathrm{dm}^{3}$ that is within the permissible limit of the World Health Organization (W.H.O) (1993) drinking water standard $\left(4.0 \mathrm{mg} / \mathrm{dm}^{3}\right)$. Therefore Fluoride ion is not present at levels that could cause toxicity.

Iron was found in all the water samples. However, the iron concentrations in some of the samples (from Powari, Gwange, Sabon Pegi, New Jerusalem and Nassarawa wards) were below the WHO maximum concentration level $\left(0.3 \mathrm{mg} / \mathrm{dm}^{3}\right)$, while the rest (from Powari cemented well, Nayinawa, Hausari, Nyanya and Tashan sassawa wards) were all above the maximum contaminant level. The result of the study revealed that the concentration of iron in some of the groundwater samples is slightly above the permissible limits of WHO, thereby suggesting that iron present in the surface water is getting precipitated and deposited as solid ferric hydroxide.

The result in Table 1 also shows that nitrite was present in all the water samples and is within the permissible limits of W.H.O. The average concentration in the samples is $0.0567 \mathrm{mg} / \mathrm{dm}^{3}$ as compared to W.H.O maximum contaminant level of $1.0 \mathrm{mg} / \mathrm{dm}^{3}$.

Most of these elements are toxic in nature and some are considered potential health hazards (Bubb and Lester, 1994; Hunt and Howard, 1994 and
Ramesh et al, 1995). The toxicity to humans which these metals can cause has already been reported (Duru and Ackman, 1991). Some of these elements are known to be toxic at high concentration and some specific trace elements, such as lead cadmium, have been linked to coronary heart disease and hypertention (Duru and Ackman, 1991). However, a number of trace elements are important in the growth and development of the body. For example, zinc is an essential dietary trace element whose deficiency was associated with hypogonadism (delayed sexual development) and dwarfism, while deficiency of selenium, an essential micronutrient was connected to cancer (Whitten et al, 2004).

The trace elements found in the groundwater are mainly due to anthropogenic addition of Municipal and agricultural chemical residues in the farmlands around Damaturu Metropolis. So many studies, Ramesh et al, (1995) and Zubair (1998) for Madras in India and Karachi in Pakistan respectively have shown that in urban environments, the human impacts is greater than the natural input of trace elements due to sewage industrial effluent discharge by the industries and municipalities. This suggests that the sources of the trace elements in ground water of the study area are mainly from human impact and not by natural inputs. It is anticipated that increase population and urbanization in the area, could increase the levels of these trace elements as well. This may be the result of the interaction of various components of the effluents with natural systems (rocks, sediments and soils) responsible for an increase in the level of pollution. Therefore there is need to control these elements at their source. 


\section{CONCLUSION}

Certain trace elements are essential because they are absolutely necessary for life processes, whereas some are toxic and are considered as potential health hazards even if present in trace quantities. Determinants such as Lead, Cadmium, Zinc and Copper were not found in all the water samples, while other traces such as Fluoride and Nitrite are within

\section{REFERENCES}

Balaram, B. (1992). "Application of ICP-MS for the Determination of Trace Elements in Environmental Samples". Proceedings, Ninth International Symposium of Analytical Techniques for Fossil Fuels and Lubricants. University of Delhi and IOL: Faridabad. pp.333-335.

Bubb J.M. and Lester J.N. (1994). Anthropogenic Heavy Metals Inputs to Low Land River System, A Case Study, The River Store. U.K, Water, Air and Soil Pollut. 78:279-297.

Duru, L.A. and Ackman, R.G. (1991). Trace elements determination in the African oil bean seed (Pentaclethra macrophylla) by the inducatively Couple plasma method. Nigerian Journal of Applied Science, Ambik Press, Benin City, Nigeria. Vol. 9: 62-66.

Hunt, L.E. and Horward A.G. (1994). Arsenic Speciation and Distribution in the Carnon Estuary following the Acute Discharge of Contamination water from a disused mine. Mar. Poll. Bull., 28, 33-38.

Ramesh, R., Shivkumar, K., Eswarmoorthi, J., and Purvaja, G.R. (1995). Migration and Contamination of Major and Trace Elements in Groundwater of Madras City, India. Environmental Geology. 25: 125-136 the permissible limits set by W.H.O. Only iron was found to exceed the limits set by W.H.O. (1993).

This study suggest that monitoring of the quality of groundwater should be undertaken regularly to identify the magnitude and source of toxic pollutants which are responsible for the contamination of groundwater quality in the study area.

United State Environmental Protection Agency (USEPA) (1986). "Quality Criteria for Water". U.S. Environmental Protection Agency, office of water regulation and standards, 440/5-86$001,453 p$.

Whitten, K.W., Davis, R.E., Peck, M.L. and Stanley, G.G. (2004). General Chemistry $7^{\text {th }}$ Edition. Brooks/Cole-Thompson Learning, Belmont, U.S.A. pp. 919-921.

World Health Organization (W.H.O.). 1993. "Guidelines for Drinking Water Quality". WHO: Geneva, Switzerland.

Zubair, A. and Farooq, M.A. (2008). "Assessments of Infiltration Rate and Effects on Water Quality of Selected Infiltration Media for use in Storm Water Runoff in Karachi, Pakistan". A Paper Presented at the Ninth International Conference on Modelling, Monitoring and Management of Water Pollution, Held on June 9-11, 2008. Alicant, Spain.

Zubair, A. and Farooq, M.A. and Abbasi, H.N. (2008). Toxic and Trace Element Pollution in Storm Water of Karachi: A Graphical Approach. The Pacific Journal of Science and Technology. 9 (1): 238-253.

Zubair, A. (1998). "Groundwater Pollution and its Environmental Impact on Health in Karachi Region, Pakistan". Ph.D. Thesis, University of Ulster: Northern Ireland, UK. 